\title{
Mitogenic properties of insulin and insulin analogues mediated by the insulin receptor
}

\author{
D. Ish-Shalom ${ }^{1}$, C. T. Christoffersen ${ }^{2}$, P. Vorwerk ${ }^{2}$, N. Sacerdoti-Sierra ${ }^{1}$, R . M. Shymko ${ }^{2}$, D. N aor ${ }^{1}$, P. D e M eyts ${ }^{2}$ \\ ${ }^{1}$ The Lautenberg Center for General and Tumour Immunology, The Hebrew University, Hadassah Medical School, \\ Jerusalem, Israel \\ 2 The Hagedorn Research Institute, Gentofte, Denmark
}

Summary Insulin has traditionally been considered as a hormone essential for metabolic regulation, while the insulin-like growth factors (IGF-I and IGF-II) are postulated to be more specifically involved in growth regulation. The conventional wisdom is that they share each other's effects only at high concentrations, due to their weak affinity for the heterologous receptor. We discuss here the evidence that in the proper cellular context, insulin can be mitogenic at physiologic concentrations through its own receptor. We studied the insulin and IGF-I binding characteristics of a new model suitable for analysing insulin receptor mediated mitogenesis; that is, a T-cell lymphoma line that depends on insulin for growth, but is unresponsive to IGFs. The cells showed no specific binding of ${ }^{125} \mathrm{I}$-IGF-I and furthermore, no IGF-I receptor mRNA was detected by RNAse protection assay in the LB cells, in contrast with mouse brain and thymus. The cells bound at sat- uration about 3000 insulin molecules to receptors that had normal characteristics in terms of affinity, kinetics, $\mathrm{pH}$ dependence and negative co-operativity. A series of insulin analogues competed for ${ }^{125}$ I-insulin binding with relative potencies comparable to those observed in other insulin target cells. The full sequence of the insulin receptor cDNA was determined and found to be identical to the published sequence of the murine insulin receptor cDNA. The LB cell line is therefore an ideal model with which to investigate insulin mitogenic signalling without interference from the IGF-I receptor. Using this model, we have started approaching the molecular basis of insulin-induced mitogenesis, in particular the role of signalling kinetics in choosing between mitogenic and metabolic pathways. [Diabetologia (1997) 40: S25-S31]

Keywords Insulin receptor, IGF-I receptor, mitogenic signalling, insulin analogues, T-cell lymphoma.
The receptors for insulin and insulin-like growth factor-I (IGF-I) belong to the family of receptor protein tyrosine kinases [1]. Although a vast body of data supports the concept that insulin stimulates cell growth in vitro and in vivo, the question of whether

Corresponding author: P. De Meyts, MD, PhD, Hagedorn Research Institute, Niels Steensens Vej 6, DK-2820 Gentofte, Denmark

A bbreviations: MAP kinase, Mitogen-activated protein kinase; MES, 2-[N-Morpholino]ethanesulphonic acid; ACES, 2[(2-Amino-2-oxoethyl)amino]ethanesulphonic acid; EPPS, $\mathrm{N}$-[2-Hydroxyethyl]piperazine-N'-[3-propanesulphonic acid]; TAPS, N-tris[Hydroxymethyl]methyl-3-aminopropanesulphonic acid; IGF-I, insulin-like growth factor-I; CHO, Chinese hamster ovary cell; HEPES, 4-[2-hydroxyethyl]-1-piperazineethanesulphonic acid; IL, interleukin; PI, phosphatidylinositol. insulin is physiologically a growth factor remains controversial (for review see [2]). Even more controversial is the question of whether insulin is capable of inducing mitogenic effects through its own receptor, or whether the growth-promoting effects of insulin result from its weak interaction with the IGF-I receptor or occur within insulin/IGF-I receptor hybrids [3, 4], or via interphosphorylation of the IGF-I receptor by the insulin receptor tyrosine kinase [5]. The response possibly depends on the cell type and its given supply of insulin and IGF-I receptors as well as the subsets of intracellular signalling molecules that are activated by either receptor. (We use the term IGF-I receptor for simplicity to designate the type 1 IGF receptor which binds both IGF-I and II and probably mediates the mitogenic effects of both growth factors [6].) 
In this brief review, we will summarize the evidence supporting the concept that the insulin receptor is fully capable of transmitting mitogenic signals, and describe a novel cell model suitable for studying such signalling by insulin.

\section{Previous evidence that the insulin receptor is mitogenic}

It is usually assumed that insulin is primarily a metabolic hormone while IGF-I is primarily a growth factor, but that they share each other's properties at high concentrations due to the weak affinity of each ligand for the other receptor $[2,7,8]$.

The fact that many cells contain both types of receptor complicates the assignment of the mitogenic effect to either receptor. When the stimulation of thymidine incorporation in a given cell type by insulin gives a poorly sensitive curve, it is usually assumed that the response is mediated through the IGF-I receptor. In a key experiment, Urs $\varnothing$ and Gammeltoft (personal communication) have shown that by transfecting NIH3T3 cells, which show a poor sensitivity to insulin, with increasing amounts of insulin receptor cDNA, the insulin dose-response curve for thymidine incorporation shifts toward lower concentrations when the cells express more insulin receptors than IGF-I receptors. These data suggest that the response now goes through the insulin receptor. In contrast, the IGF-I curve becomes less sensitive. It has been suggested that when co-expressed, the receptor present in excess inhibits the other's mitogenic potential, either through hybrid receptor formation or by competition for intracellular substrates $[8,9]$.

Other experimental evidence suggests that the insulin receptor tyrosine kinase has oncogenic potential. Wang et al. [10] showed that a chimeric retrovirus (UIR) with the ros sequence of the avian sarcoma virus UR2 with human insulin receptor cDNA sequences coding for 46 residues of the extracellular domain and the entire transmembrane and cytoplasmic domains of the insulin receptor $\beta$ subunit was capable of transforming chicken embryo fibroblasts and promoting formation of colonies in soft agar. A variant that arose from the parental UIR efficiently induced sarcomas in vivo in chickens (Fig. 1).

While this demonstration of the oncogenic potential of a constitutively activated insulin receptor tyrosine kinase was performed in a clearly artificial system, recent data with insulin analogues have also raised concerns about the potential carcinogenicity of some modified insulins, and the need for accurate tests thereof. The fast acting (in vivo) insulin analogue $\mathrm{Asp}^{\mathrm{B} 10}$ insulin was indeed found to induce both benign (fibroepithelial adenomas) and malignant (adenocarcinomas) mammary tumours in female rats [11]. It was also found to be supermitogenic

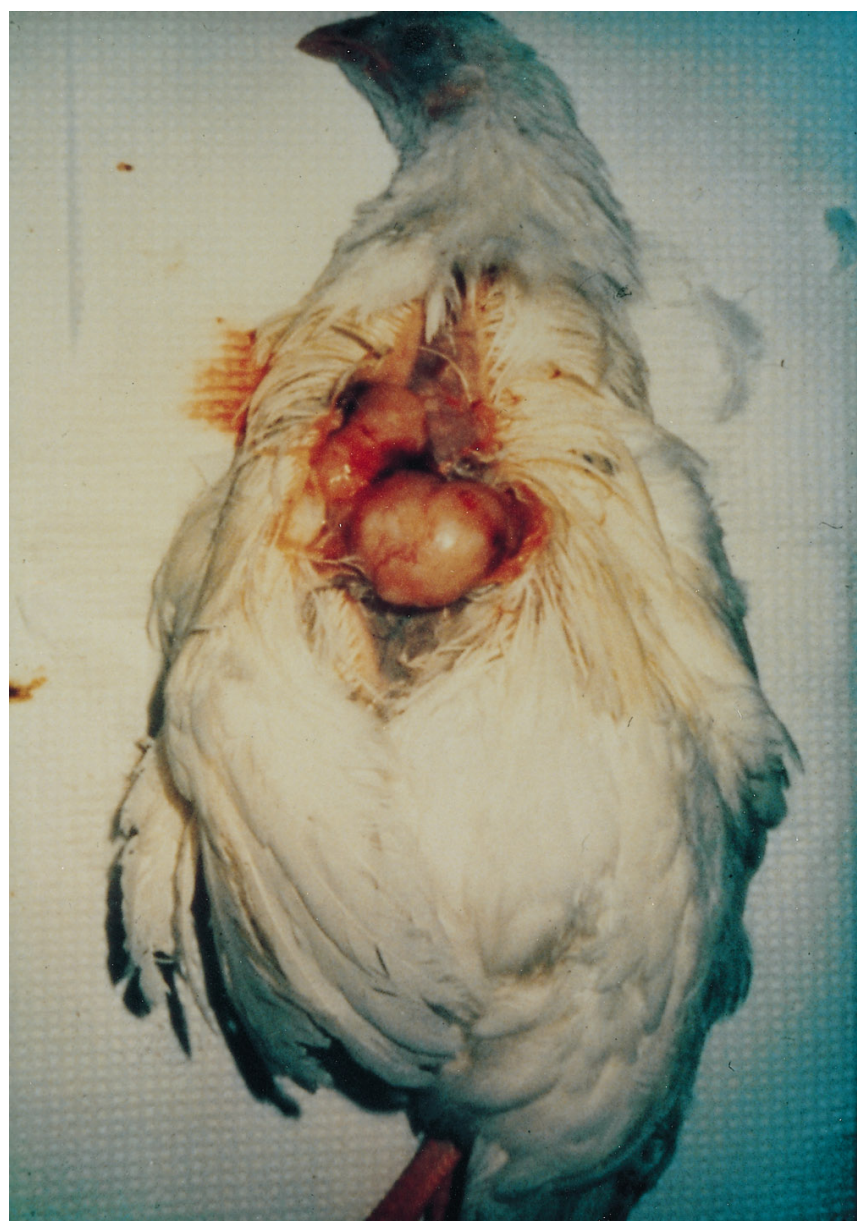

Fig. 1. Induction of sarcoma in chicken by chick embryo fibroblasts transformed by a constitutively activated insulin receptor tyrosine kinase. Reproduced with permission from [45]. Figure kindly provided by W.J. Rutter

in vitro in that its potency to stimulate thymidine incorporation in vascular smooth muscle cells was 10 20 times higher than expected from its affinity for the insulin receptor [12]. We [13] and others [14] found that this enhanced mitogenicity is a general property of analogues with a prolonged residence time on the insulin receptor relative to native insulin, due to a slower dissociation rate, as discussed below.

Finally, there is some circumstantial evidence that chronic hyperinsulinaemia may be correlated with breast cancer risk in humans [15].

\section{Cell models suitable for investigating insulin's mitogenic effects}

To the best of our knowledge, only hepatoma cell lines such as H35 or KRC7 have been shown to lack IGF-I binding and to still exhibit sensitive insulin-dependent growth and thymidine incorporation [16-18]. A few other cell lines (such as the F9 embryonal carcinoma cell line [19] and RPMI-8226 [20]) show sensitive 
insulin mitogenic responses but the status of IGF-I receptors in these cells has not been established. Mamounas et al. [21, 22] have established an interesting insulin-dependent Chinese hamster ovary cell line (CHO-K1) where insulin appears to be mitogenic through its own receptor; however, this cell line also binds IGF-I. In no case has the status of IGF-I receptors been ascertained by methods other than ligand binding.

Lammers et al. [23] have used NIH3T3 cells overexpressing chimeric insulin and IGF-I receptor constructs in order to compare the intrinsic mitogenic potency of their respective intracellular domains, and found only a 10-fold difference between the potencies of the insulin and IGF-I receptor domains. There is however a general problem with using cellular overexpression of receptors or signalling molecules, in that the high level of expression may overcome low affinities and promote interactions that would not occur under more physiological conditions.

We have recently explored a novel in vitro model, the LB cell lymphoma line, well suited to the investigation of the mitogenic signalling through the insulin receptors [24].

\section{The L B T lymphoma line}

The LB cell line is a murine T-cell lymphoma designated LB that demonstrates insulin-dependent growth. This very invasive tumour [25], initially qualified as a lymphoid T-cell leukemia, arose spontaneously in a 6-month-old BALB/c mouse in the animal colony of the Academia Nacional de Medicina in Buenos Aires [26, 27]. It was noticed that the cells grew much better in medium containing insulin than in medium lacking it [28]. Thymidine incorporation into LB cells (as well as cell number) was markedly stimulated over a wide range of insulin concentrations (including low physiological), but produced only a negligible response to IGF-I and none to IGF-II [28]. The cell proliferation was blocked by anti-insulin antibodies. In a previous characterization, the cells were shown to bind ${ }^{125}$ I-insulin and to contain around 3200 high affinity insulin binding sites [28]. Furthermore, insulin deficiency generated by a low energy diet or streptozotocin-induced insulin-dependent diabetes produced resistance to lymphoma growth in mice [29], demonstrating insulin dependence in vivo.

\section{Characteristics of the insulin receptor on the $L B$ cells}

G rowth characteristics in vitro. Although the LB cells could be entirely grown in vitro in suspension in complete RPMI 1640 medium containing insulin, their doubling time was slow (4 days, vs e.g. 1 day for EBV-transformed human lymphocytes [unpublished

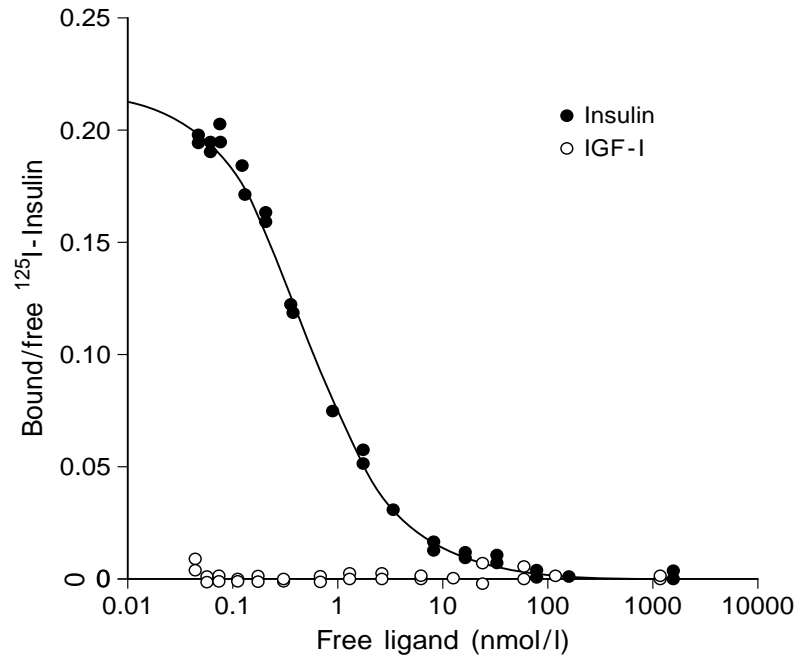

Fig. 2. Competition curves for binding of ${ }^{125} \mathrm{I}$-insulin and ${ }^{125} \mathrm{I}-$ IGF-I to LB cells. ${ }^{125}$ I-insulin or ${ }^{125}$ I-IGF-I $\left(2 \times 10^{-11} \mathrm{~mol} / \mathrm{l}\right)$ was incubated in binding buffer with $3-5 \times 10^{7} \mathrm{LB}$ cells for $4 \mathrm{~h}$ at $4^{\circ} \mathrm{C}$ in the presence of increasing concentrations of unlabelled ligand $(0-1.7 \mu \mathrm{mol} / \mathrm{l})$ or analogues at appropriately scaled concentrations. At the end of incubation, duplicate $200 \mu \mathrm{l}$ aliquots were placed in Eppendorf Microfuge tubes containing $200 \mu \mathrm{l}$ prechilled buffer and centrifuged at $10000 \mathrm{~g}$ for $5 \mathrm{~min}$. The supernatants were aspirated and the pellets counted in a gamma counter with $80 \%$ efficiency. The radioactivity bound to the cells in the presence of $1.7 \mu \mathrm{mol} / \mathrm{l}$ unlabelled ligand was subtracted as non-specific binding. Specific binding (as bound/free ligand) is plotted as a function of free ligand concentration. The competition data were analysed on a Sun workstation using non-linear curve-fitting programs developed at the Hagedorn Research Institute. A negative co-operativity model assuming one high-affinity and one low affinity bound ligand per receptor heterotetramer [7] was used to fit the data. The model was expressed as a two-site Adair model [43] with dissociation constant $\mathrm{K}_{\mathrm{d} 1}$ different from $\mathrm{K}_{\mathrm{d} 2}$ but receptor site concentration $\mathrm{R}_{1}=\mathrm{R}_{2}$

observations]). This slow growth rate in vitro made it more feasible, in order to obtain large numbers of cells, to maintain them by serial passage in the peritoneal cavity of syngeneic mice [26]. One half millilitre of cell suspension $\left(2 \times 10^{6}\right.$ cells/ml RPMI) was injected into the peritoneal cavity of 6-week-old female $\mathrm{BALB} / \mathrm{c}$ mice. One week later, ascites was removed. The cells were washed three times in HEPES (4-[2hydroxyethyl]-1-piperazine-ethanesulphonic acid) binding buffer before further studies.

Insulin and IGF-I binding. Preliminary experiments (not shown) determined that steady-state ${ }^{125}$ I-insulin binding was reached after $3 \mathrm{~h}$ at $4{ }^{\circ} \mathrm{C}$. The curve for competition of ${ }^{125}$ I-insulin by increasing amounts of unlabelled insulin (Fig. 2) showed high affinity binding $\left(\mathrm{IC}_{50} \sim 0.5 \mathrm{nmol} / \mathrm{l}\right)$. In contrast, no specific binding of ${ }^{125} \mathrm{I}$-IGF-I could be demonstrated; there was only $0.1 \%$ of non-specific binding (Fig. 2).

RNA se protection assay of IGF-I receptor mRNA. The absence of ${ }^{125}$ I-IGF-I binding sites on the LB 


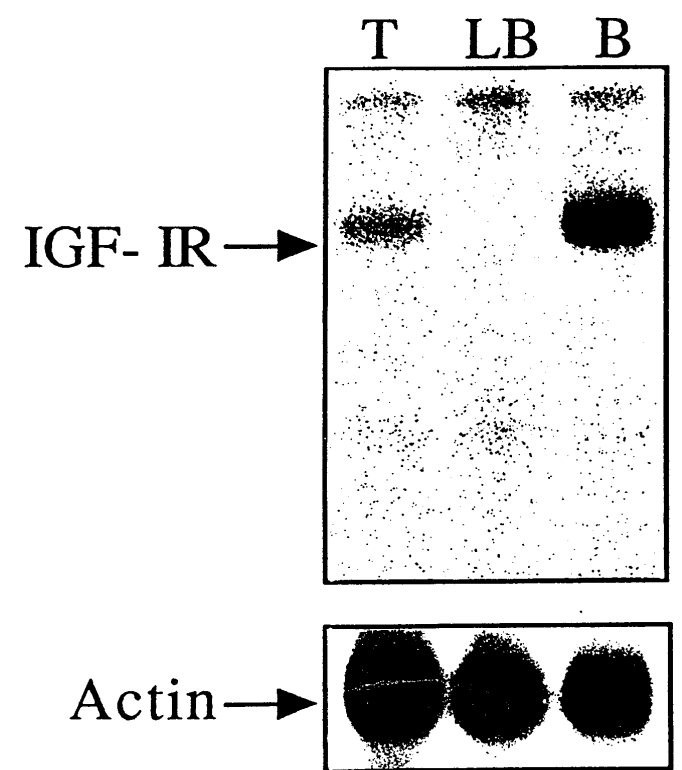

Fig. 3. RNAse protection assay of IGF-I receptor mRNA. L eft lane: RNA from BALB/c mouse thymus. Middle lane: RNA from LB cells. Right lane: RNA from BALB/c mouse brain. Top: IGF-I receptor probe. B ottom: $\beta$-actin probe. Solution hybridization/RNAse protection assay was performed as previously described [44], with slight modification. Briefly, $20 \mu \mathrm{g}$ of total RNA was hybridized with $1 \times 10^{6} \mathrm{cpm}$ of ${ }^{32} \mathrm{P}$-labelled antisense RNA probe of IGF-I receptor (or $\beta$-actin probe). Hybridization was performed in a buffer containing $75 \%$ formamide at $42^{\circ} \mathrm{C}$ for $16 \mathrm{~h}$. After hybridization, RNA samples were digested with RNAse A at $2 \mu \mathrm{g} / \mathrm{ml}$ and RNAse T1 at $1.1 \mu \mathrm{g} / \mathrm{ml}$ for $15 \mathrm{~min}$ at $30^{\circ} \mathrm{C}$, ethanol-precipitated and electrophoresed on an $8 \%$ polyacrylamide $/ 8 \mathrm{~mol} / \mathrm{l}$ urea denaturing gel. The gel was dried and exposed to X-ray film at $-70^{\circ} \mathrm{C}$ using an intensifying screen. The plasmid used for preparation of ${ }^{32} \mathrm{P}$-labelled rat IGF-I receptor antisense RNA was a gift from Dr. D. LeRoith (Diabetes Branch, National Institutes of Health, Bethesda, MD., USA)

cells was confirmed by RNAse protection assay (Fig. 3).

The presence of mRNA for the IGF-I receptor was demonstrated in the brain and thymus of BALB/c mice using a probe for the rat IGF-I receptor; in contrast, no IGF-I mRNA was detected in the same amount of total RNA from LB cells. Similar amounts of actin mRNA as control were detected in all three samples.

Properties of the insulin receptor on L B cells. Since overexpression of insulin receptors or expression of an abnormal insulin receptor on LB cells may be associated with the malignant state, we undertook a detailed characterisation of the insulin receptor on these cells.

The insulin equilibrium binding data showed excellent fit (Figs. 2 and 4) to a model of negative co-operativity assuming one molecule of ligand bound with high affinity $\left(\mathrm{K}_{\mathrm{d} 1}=0.88 \mathrm{nmol} / \mathrm{l}\right)$ and one with low affinity $\left(\mathrm{K}_{\mathrm{d} 2}=5.5 \mathrm{nmol} / \mathrm{l}\right)$ per receptor

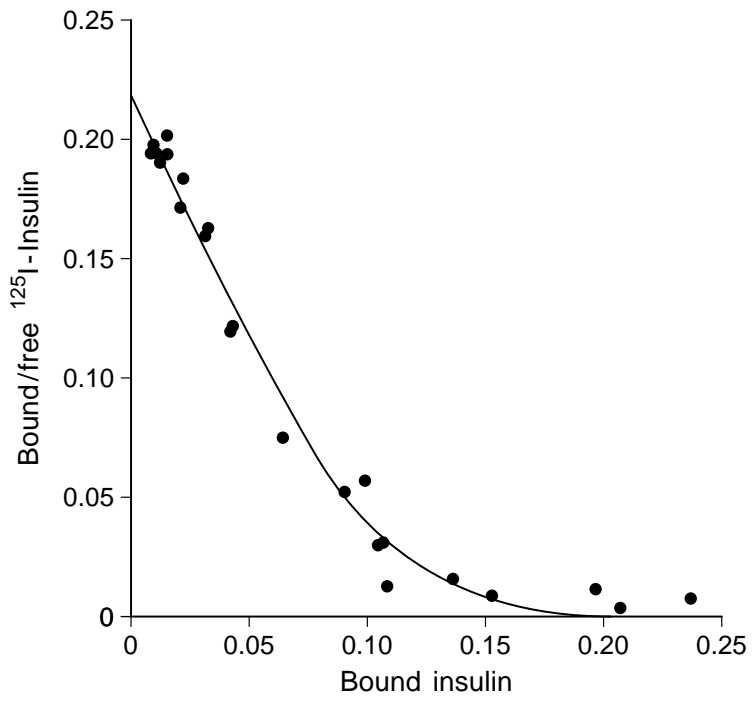

Fig. 4. Scatchard plot of insulin binding to LB cells. The computer-fitted insulin competition data of Figure 2 are displayed as bound/free vs bound insulin

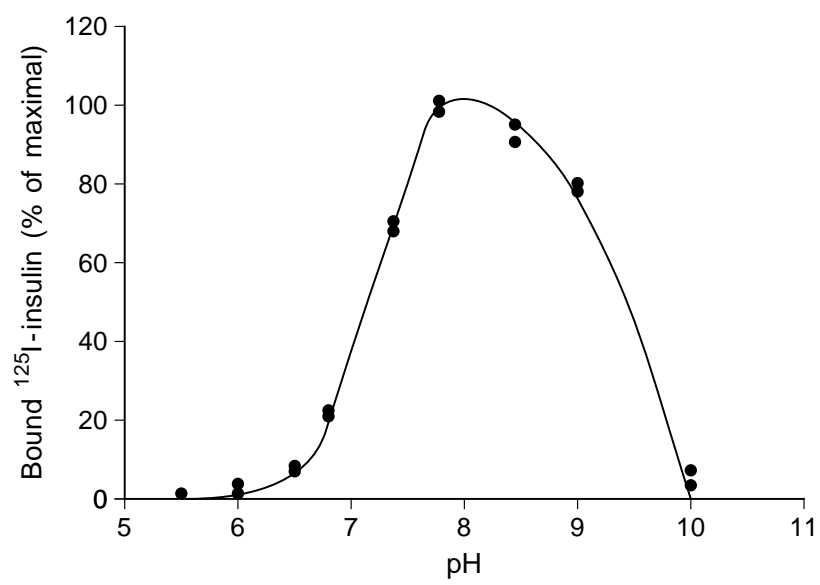

Fig. 5. $\mathrm{PH}$ dependence of ${ }^{125} \mathrm{I}$-insulin binding to LB cells. ${ }^{125} \mathrm{I}$ insulin $\left(1.7 \times 10^{-11} \mathrm{~mol} / \mathrm{l}\right)$ was incubated with LB cells $\left(5 \times 10^{7} /\right.$ $\mathrm{ml})$ in the absence or presence of $1.7 \mu \mathrm{mol} / \mathrm{l}$ unlabelled insulin (non-specific binding) in $500 \mu \mathrm{l}$ binding buffer adjusted to the appropriate $\mathrm{pH}$. The buffer composition was the same as above except that the following buffering agents were used (100 mmol/l): pH 5.5-6: 2-[N-morpholino]ethanesulphonic acid (MES); pH 6.2-6.8: 2-[(2-Amino-2-oxoethyl)amino]ethane sulphonic acid] (ACES); pH 7.2-7.6: HEPES; pH 7.4-7.8: N-[2-Hydroxyethyl]piperazine-N'-[3-propane sulphonic acid] [EPPS]; pH 8-9: N-tris[Hyroxymethyl]methyl-3aminosulphonic acid [TAPS]; $\mathrm{pH}$ 10: glycine (all from Sigma, St. Louis, MO, USA). After $4 \mathrm{~h}$ at $4^{\circ} \mathrm{C}$, duplicate $200 \mu \mathrm{l}$ from each tube were centrifuged and processed as described in the legend of Figure 2

heterotetramer, a model previously shown to apply to insulin as well as IGF-I binding to multiple cell types $[7,30]$. The total number of binding sites was only 3000 , corresponding to 1500 receptors per cell assuming half of the sites were reactive [7].

The $\mathrm{pH}$ dependence of binding showed a bellshaped curve with a maximum at $\mathrm{pH} 7.6$ (Fig. 5) as 


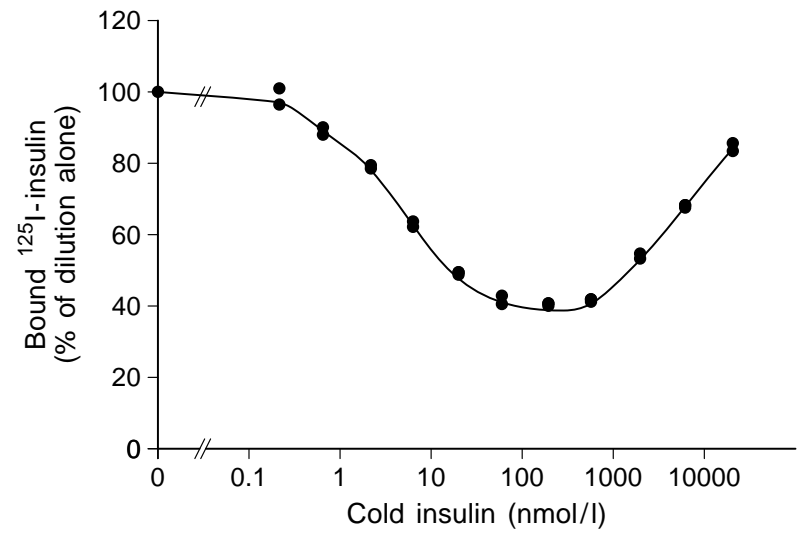

Fig. 6. Dose-response curve for negative co-operativity of the LB cell insulin receptor. The ability of unlabelled insulin to accelerate the dissociation rate of ${ }^{125} \mathrm{I}$ - insulin at high dilution, the hallmark of negative co-operativity $[7,30,31]$ was studied as a function of unlabelled insulin concentration in the dilution medium as previously described [31]. Briefly, $10^{-10} \mathrm{~mol} / \mathrm{l}^{125} \mathrm{I}$-insulin was incubated with $3 \times 10^{8} \mathrm{LB}$ cells in $1 \mathrm{ml}$ buffer at $4{ }^{\circ} \mathrm{C}$ for $3 \mathrm{~h}$ and then centrifuged. The supernatant was aspirated and the pellet was resuspended in $1 \mathrm{ml}$ ice-cold buffer, from which $25 \mu \mathrm{l}$ aliquots were quickly transferred into duplicate tubes containing $1 \mathrm{ml}$ binding buffer $\left(4^{\circ} \mathrm{C}\right)$ with increasing concentrations of unlabelled insulin $(0-8 \mu \mathrm{mol} / \mathrm{l})$. The dissociation was allowed to proceed for $30 \mathrm{~min}$, after which the tubes were centrifuged and the pellets counted

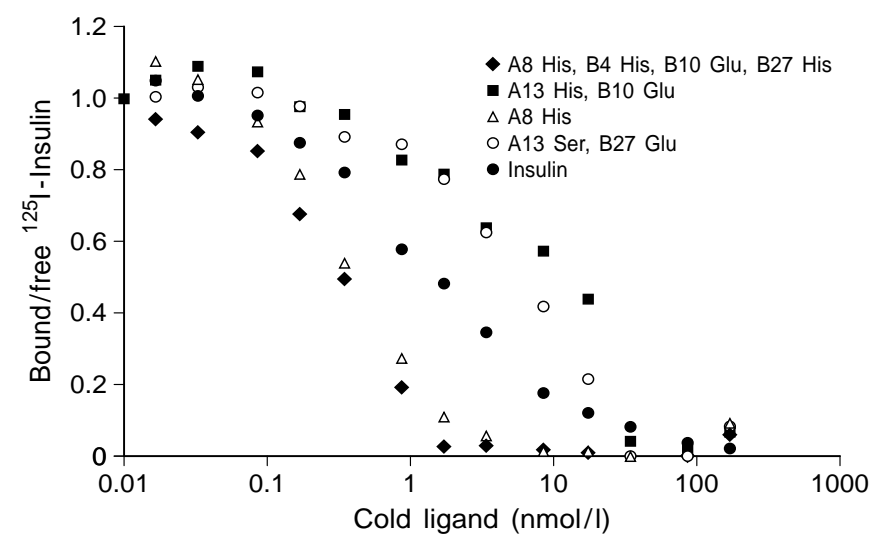

Fig. 7. Competition of insulin analogues for ${ }^{125} \mathrm{I}$-insulin binding to LB cells. ${ }^{125}$ I-insulin was incubated with LB cells in the presence of various insulin analogues at the indicated concentrations. Specific tracer binding is plotted vs analogue concentration

previously found for the insulin receptor on other target cells [31].

Insulin dissociation kinetics displayed typical features of negative co-operativity [30, 32, 33]. The dissociation rate of ${ }^{125}$ I-insulin was accelerated by unlabelled insulin with a bell-shaped dose-response curve identical to that previously described in various cell types (Fig.6), with a maximum effect obtained with $100 \mathrm{nmol} / \mathrm{l}$ unlabelled insulin.

A number of insulin analogues (four are shown in Fig. 7) competed for ${ }^{125}$ I-insulin binding with relative potencies comparable to those shown previously for the insulin receptor in HepG2 cells [34, 35] and to their biological potency in the free fat cell assay [34, 35]. Collectively, these results indicate that the LB cell insulin receptor does not exhibit exceptional properties as compared to other insulin receptors. To further establish this conclusion, the cDNA sequence of the LB insulin receptor was analysed.

Sequence of the $L B$ cell insulin receptor $C D N A$. The LB cell insulin receptor cDNA sequence was identical to the published mouse sequence [36] with the exception of two silent single base changes. Since we found the same variations in the control liver cDNA from BALB/c mice, these variations most likely represent sequencing errors in the published sequence or allelic polymorphisms. Moreover, we found a $\mathrm{C}$ at bp position 3314 which is in agreement with the published sequence [36] but in disagreement with the database sequence which has $\mathrm{T}$ at this position (accession nr.: J05149.GB RO; GenEMBL), which is probably an error since again we found the same variation in $\mathrm{BALB} / \mathrm{c}$ mouse liver cDNA. The change from $\mathrm{T}$ to $\mathrm{C}$ would change the corresponding amino acid (at position 1062) from methionine to threonine.

In summary, we have clearly documented by both ligand binding studies and RNAse protection assay the complete absence of IGF-I receptors in LB cells. Therefore, the observed mitogenic response is clearly mediated through the insulin receptor. Unlike a number of mutant insulin receptors [37], the small number (1500) of LB cell insulin receptors present have the normal binding characteristics of the insulin receptor previously described on other target cells: affinity, $\mathrm{pH}$ dependence, negative co-operativity and relative affinity for insulin analogues. Moreover, the sequence of the receptor cDNA was essentially identical to the published murine sequence, with the exception of two residue differences also present in the liver of control BALB/c mice and therefore likely to represent sequencing errors in the published sequence or allelic variants.

The presence of insulin receptors and the absence of IGF-I receptors on a T-cell line is not a common phenomenon, although it has only been systematically investigated in human cell lines. Typically, most human T-cell lines will have IGF-I but not insulin receptors, while the reverse is true for B-cell lines [38, 39]. Lee et al. [38] suggested that IGF-I and insulin receptors may be markers of lymphocyte differentiation and that these peptide growth factors may play a role in lymphocyte metabolism.

Besides insulin, LB cell proliferation is also stimulated by interleukin (IL)-2 [28], IL-4 (Urs $\varnothing$, B., unpublished data), $\gamma$-interferon, concanavalin A, and phorbol 12-myristate 13-acetate (PMA) (Naor, D., unpublished data), and inhibited by tumour necrosis factor $\alpha$ in the presence of serum (Urs $\varnothing$, B., unpublished 
data). Recently, we found that human growth hormone is also a powerful mitogen for the LB cells (Ilondo, M.M. et al, manuscript in preparation). In contrast, they do not respond to IL-I, platelet-derived growth factor or c-kit (Urs $\varnothing$, B., unpublished data). Altogether, these findings suggest that LB cells exploit, in addition to insulin, other growth signals, which may collaborate with insulin or exert an independent stimulus.

The nature of the oncogene(s) responsible for the malignancy and invasiveness of the LB lymphoma is unclear. It is clearly not an abnormal insulin receptor, but one factor could be the lack of IGF-I receptors if the above-mentioned hypothesis that the two receptors keep each other's mitogenic potential in check is correct. It could also be that a downstream signalling molecule is mutated, constitutively activated or abnormally expressed, making it overresponsive to insulin or resistant to downregulation control mechanisms.

In any case the LB cells should be an interesting new model with which to investigate insulin mitogenic signalling without interference from the IGF-I receptor.

\section{M itogenic signalling pathway of insulin in the L B lymphoma cells}

Our preliminary data indicate that both the Ras/Raf/ MEK/MAP kinase pathways and the phosphatidylinositol (PI)-3 kinase pathways are active in the LB cells, but that mitogen activated protein (MAP) kinase is much less stimulated by insulin than PI-3 kinase, in line with much recent evidence in a variety of systems that tends to downplay the importance of MAP kinase in a number of insulin effects (reviewed in [40]). The effect of specific inhibitors of MAP kinase/extracellular signal regulated protein kinase (MEK) (PD-098059) and PI-3 kinase (LY24009), which partially inhibited the mitogenic response to insulin, was difficult to interpret since the inhibitors also inhibited at similar doses the basal level of thymidine incorporation in the absence of insulin, suggesting perhaps that a tonic basal level of both pathways is permissive for mitogenesis, but not allowing firm conclusions as to their role in insulin stimulation. We are also exploring, based on preliminary evidence, the possibility that the LB cells express an insulin substrate docking protein different from IRS-1 and IRS-2 (Urs $\varnothing$, B. et al., in preparation).

\section{Conclusions: what is the molecular basis} of the mitogenic compared to metabolic specificity of insulin and IG F-I?

It is obvious from the above brief survey that at this point we do not have a clear understanding of the molecular mechanisms that determine how insulin or IGF-I trigger mitogenic or metabolic effects through their own or each other's receptors in a given cell type. This problem is compounded by the fact that both ligands appear capable of stimulating the same network of signalling cascades in various cells (reviewed in [8, 41, 42]).

The finding that mitogenic effects are selectively enhanced by an increased residence time of insulin analogues on the receptor $[13,14]$, resulting, in $\mathrm{CHO}$ cells overexpressing the insulin receptor, in a sustained activation of the insulin receptor tyrosine kinase and phosphorylation of Shc [14], suggests that a detailed investigation of the kinetics of downstream signalling is required in order to fully understand the molecular basis of signalling specificity. The LB cell line will be a useful model with which to pursue this line of investigation.

A cknowledgements. The Hagedorn Research Institute is a basic research component of Novo Nordisk.

\section{References}

1. Ullrich A, Schlessinger J (1990) Signal transduction by receptors with tyrosine kinase activity. Cell 61: 203-212

2. Moses AC, Tzuzaki S (1991) Is insulin a growth factor? In: LeRoith D (ed) Insulin-like growth factors, molecular and cellular aspects. CRC Press, Boca Raton Ann Harbor Boston London, pp 245-270

3. Soos MA, Field CE, Siddle K (1993) Purified hybrid insulin/insulin-like growth factor-I receptors bind insulin-like growth factor-I, but not insulin, with high affinity. Biochem J 290: 419-426

4. Sweet LJ, Morrison BD, Pessin J (1987) Isolation of functional a-b heterodimers from the purified human placental $\alpha 2-\beta 2$ heterotetrameric insulin receptor concept. Structural basis for high affinity ligand binding. J Biol Chem 262: 6939-6942

5. Beguinot F, Smith RJ, Kahn CR, Maron R, Moses AC, White MF (1988) Phosphorylation of insulin-like growth factor-I receptor by insulin receptor tyrosine kinase in intact cultured skeletal muscle cells. Biochemistry 27: 3222-3228

6. Moxham C, Jacobs S (1992) Insulin-like growth factor receptors. In: Schofield P (ed) The insulin-like growth factors. Structure and biological functions. Oxford University Press, Oxford New York Tokyo, pp 80-109

7. De Meyts P (1994) The structural basis of insulin and insulin-like growth factor-I (IGF-I) receptor binding and negative co-operativity, and its relevance to mitogenic versus metabolic signalling. Diabetologia 37[Suppl 2]:S135-S148

8. De Meyts P, Wallach B, Christoffersen CTet al. (1994) The insulin-like growth factor-I receptor. Structure, ligand binding mechanism and signal transduction. Horm Res 42: 152-169

9. Maggi D, Laurino C, Andraghetti G, Cordera R (1994) The overexpression of insulin receptor makes $\mathrm{CHO}$ cells resistant to the action of IGF-I. Role of IRS-1. Biochem Biophys Res Commun 205: 693-699

10. Wang LH, Lin B, Jong S-MJ, Dixon D, Ellis L, Roth RA, Rutter WJ (1987) Activation of the transforming potential of the human insulin receptor gene. Proc Natl Acad Sci USA 84: 5725-5729 
11. Dideriksen LH, Jørgensen LN, Drejer K (1992) Carcinogenic effect on female rats after 12 months administration of the insulin analogue B10 Asp. Diabetes 41 [Suppl 1]:143A (Abstract)

12. Bornfeldt KE, Gidlöf RA, Wasteson A, Lake M, Skottner A, Arnqvist HJ (1991) Binding and biological effects of insulin, insulin analogues and insulin-like growth factors in rat aortic smooth muscle cells. Comparison of maximal growth-promoting activities. Diabetologia 34: 307-313

13. De Meyts P, Christoffersen CT, Urs $\varnothing$ B et al. (1993) Insulin potency as a mitogen is determined by the half-life of the insulin-receptor complex. Exp Clin Endocrinol Leipzig 101: 22-23

14. Hansen BF, Danielsen GM, Drejer K et al. (1996) Sustained signalling from the insulin receptor after stimulation with insulin analogues exhibiting increased mitogenic potency. Biochem J 315: 271-279

15. Kaaks R (1996) Nutrition, hormones, and breast cancer: Is insulin the missing link? Cancer causes and control 7: 605625

16. Koontz JW, Iwahashi M (1981) Insulin as a potent, specific growth factor in a rat hepatoma cell line. Science 211: 947-949

17. Petersen B, Blecher M (1979) Insulin receptors and functions in normal and spontaneously transformed cloned rat hepatocytes. Exp Cell Res 120: 119-125

18. Hofmann C, Marsh JW, Miller B, Steiner DF (1980) Cultured hepatoma cells as a model system for studying insulin processing and biologic responsiveness. Diabetes 29: 865874

19. Nagarajan L, Anderson WB (1982) Insulin promotes the growth of F9 embryonal cells apparently by acting through its own receptor. Biochem Biophys Res Commun 106: 974-980

20. Freund GG, Kulas DT, Mooney RA (1993) Insulin and IGF-I increase mitogenesis and glucose metabolism in the multiple myeloma cell line, RPMI-8226. J Immunol 151: $1811-1820$

21. Mamounas M, Gervin D, Englesberg E (1989) The insulin receptor as a transmitter of a mitogenic signal in Chinese hamster ovary CHO-K1 cells. Proc Natl Acad Sci U.S.A. 86: 9294-9298

22. Mamounas M, Ross S, Luong CL et al. (1991) Analysis of the genes involved in the transmembrane mitogenic signal in Chinese hamster ovary cells, CHO-K1, utilizing insulinindependent mutants. Proc Natl Acad Sci USA 88: 35243530

23. Lammers R, Gray A, Schlessinger J, Ullrich A (1989) Differential signalling potential of insulin- and IGF-I-receptor cytoplasmic domains. EMBO J 8: 1369-1375

24. Ish-Shalom D, Tzivion G, Christoffersen CT, Urs $\varnothing$ B, De Meyts P Naor D (1995) Mitogenic potential of insulin on lymphoma cells lacking IGF-I receptors. Ann N Y Acad Sci 766: 409-415

25. Zahalka AM, Okon E, Gosslar U, Holzmann B, Naor D (1995) Lymph node (but not spleen) invasion by murine lymphoma is both CD44- and hyaluronate dependent. J Immunol 154: 5345-5355

26. Ruggiero RA, Bustuoabad OD, Bonfil RD, Meiss RP, Pasqualini CD (1985) "Concomitant immunity" in murine tumours of non-detectable immunogenicity. Brit J Cancer 51: 37-48

27. Meiss RP, Bonfil RD, Ruggiero RA, Pasqualini CD (1986) Histologic aspects of concomitant resistance induced by non-immunogenic murine tumours. J Natl Cancer Inst 76: 1163-1175
28. Pillemer G, Lugasi-Evgi H, Scharovski G, Naor D (1992) Insulin dependence of murine lymphoid T-cell leukemia. Int J Cancer 50: 80-85

29. Sharon R, Pillemer G, Ish-Shalom D et al. (1993) Insulin dependence of murine T-cell lymphoma. 2. Insulin-deficient mice and mice fed low-energy diet develop resistance to lymphoma growth. Int J Cancer 53: 843-849

30. Christoffersen CT, Bornfeldt KE, Rotella CM et al. (1994) Negative co-operativity in the insulin-like growth factor-I (IGF-I) receptor and a chimeric IGF-I/insulin receptor. Endocrinology 135: 472-475

31. De Meyts P (1976) Insulin and growth hormone receptors in human cultured lymphocytes and peripheral blood monocytes. In: Blecher M (ed) Methods in receptor research. Marcel Dekker, New York, pp 301-383

32. De Meyts P, Bianco AR, Roth J (1976) Site-site interactions among insulin receptors: characterization of the negative co-operativity. J Biol Chem 251: 1877-1888

33. De Meyts P, Van Obberghen E, Roth J, Brandenburg D, Wollmer A (1978) Mapping of the residues of the receptor binding region of insulin responsible for the negative cooperativity. Nature 273: 504-509

34. Brange J, Owens D, Kang S, Vølund A (1990) Monomeric insulins and their experimental and clinical implications. Diabetes Care 13: 923-954

35. Drejer K (1992) The bioactivity of insulin analogues from in vitro receptor binding to in vivo glucose uptake. Diabetes Metab Rev 8: 259-286

36. Flores-Riveros JR, Sibley E, Kastelic C, Lane MD (1989) Substrate phosphorylation catalyzed by the insulin receptor tyrosine kinase. Kinetic correlation to autophosphorylation of specific sites in the beta subunit. J Biol Chem 264: 21557-21572

37. Taylor S, Cama A, Accili D et al. (1992) Mutations in the insulin receptor gene. Endocrine Rev 13: 566-595

38. Lee PD, Rosenfeld RG, Hintz RL, Smith SD (1986) Characterization of insulin, insulin-like growth factors I and II, and growth hormone receptors on human leukemic lymphoblasts. J Clin Endo Metab 62: 28-35

39. Braciale VL, Gavin JRI, Braciale TJ (1982) Inducible expression of insulin receptors on $\mathrm{T}$ lymphocyte clones. $\mathrm{J}$ Exp Med 156: 664-669

40. De Meyts P, Christoffersen CT, Tornqvist H, Seedorf K (1996) Insulin receptors and insulin action. Curr Opinion Endo Diab 3: 369-377

41. De Meyts P, Christoffersen CT, Urs $\varnothing$ B et al. (1995) Role of the time factor in signalling specificity. Application to mitogenic and metabolic signalling by the insulin and insulinlike growth factor-I receptor tyrosine kinases. Metabolism 44[Suppl 4]:1-11

42. De Meyts P, Urs $\varnothing$ B, Christoffersen CT, Shymko RM (1995) Mechanism of insulin and IGF-I receptor activation and signal transduction specificity. Receptor dimer crosslinking, bell-shaped curves, and sustained versus transient signalling. Ann New York Acad Sci 766: 388-401

43. Adair GS (1925) The hemoglobin system. VI. The oxygen dissociation curve of hemoglobin. J Biol Chem 63: 529-545

44. Werner H, Woloschak M, Adamo M, Shen-Orr Z, Roberts CT Jr, LeRoith D (1989) Developmental regulation of the rat insulin-like growth factor-I receptor gene. Proc Natl Acad Sci 86: 7451-7455

45. Rutter WJ, Morgan D, Ebina Y, Wang LH, Roth R, Ellis L (1988) Membrane linked insulin receptor tyrosine kinase stimulates the insulin specific response. In: Goren HJ, Hollenberg MD, Roncari DAK (eds) Insulin action and diabetes. Raven Press, New York, pp 1-12 